\title{
Hubungan Pajanan Kebisingan dengan Tekanan Darah dan Denyut Nadi pada Pekerja Industri Kemasan Semen
}

\author{
Siswati ${ }^{1}$, Retno Adriyani $^{2}$ \\ ${ }^{1}$ Departemen Kesehatan Lingkungan, Fakultas Kesehatan Masyarakat, Universitas Airlangga \\ ${ }^{2}$ Dosen Departemen Kesehatan Lingkungan, Fakultas Kesehatan Masyarakat, Universitas Airlangga \\ Corresponding author: retnoadriyani@fkm.unair.ac.id
}

Info Artikel : Diterima Maret 2017 ; Disetujui Maret 2017 ; Publikasi April 2017

\begin{abstract}
ABSTRAK
Latar belakang: Cemaran bising merupakan merupakan suara yang mengganggu dan membahayakan orang yang mendengarnya. Gangguan suara ini dapat menimbulkan berbagai respon psikologis, khusunya pada sistem kardiovaskuler pada orang-orang yang terpapar. Penelitian ini bertujuan untuk menganalisis hubungan antara paparan bising dengan tekanan daran dan denyut nadi pada pekerja industi kemasan semen.

Metode: Penelitian dengan disain cross sectional telah dilakukan di industri kemasan semen di Tuban Indonesia. Sampel diambil sebanyak 22 pekerja denan teknik random random. Pengukuran tingkat kebisingan dilakukan di unit produksi menggunakan Sound Level Meter. Pengumpulan data karakteristik pekerja dilakukan dengan menggunakan kuesioner. Pengukuran tekanan daran dan denyut nadi dilakukan pada pekerja sebelum dan sesudah terpapar bising menggunakan tensimeter digital. Data penelitian dianalisis menggunakan paired t-test dan korelasi Perason pada level signifikasi 5\%.

Hasil: Tingkat bising di seluruh area unit produksi melebihi nilai ambang batas (lebih $85 \mathrm{dBA}$ ). Sebagian besar pekerja berumur 42 tahun., telah bekerja selama 15 tahun. Sebanya 77,3\% pekerja menggunakan alat pelindung telinga berupa ear plug saat bekerja. Tenanan darah sistolik maupun diastolik sebelum terpapar bising adalah normal, akan tetapi setelah terpapar bising menunjukkan gejala pre hipertensi. Rerata denyut nadi pekerja sebelum dan sesudah terpapar bising masing-masing 76,64 x/menit dan 86,91 x/menit.

Simpulan: Ada perbedaan secara signifikan (tekanan daran sistolik, diastolik, dan denyut nadi) antara sebelum dan sesudah bekerja (terpapar bising). Ada hubungan signifiakan antara tingkat bising dengan peningkatan tekanan darah sistolik, diastlik, dan denyut nadi pekerja industri kemasan semen. Para pekerja disarankan untuk selalu menggunakan alat penuutup telingan saat melakukan pekerjaannya.
\end{abstract}

Kata kunci: Kebisingan; tekanan darah sistolik dan diastolik; denyut nadi; Tuban.

\section{ABSTRACT}

Title: The Relationship between Noise Exposure with Blood Pressure and Pulse of Workers in a Cement Packaging Industry

Background: Noise pollution is the distrubing or excessive noise that may annoying, distracting or even harmfull to the people who hear it. Noise pollution can induces alteration of various physiological responses, especially on the cardiovascular system, in people exposed to it. The aim of the study was to analyze the relationship between noise exposure with blood pressure and pulse of workers in cement packaging industry.

Method: A cross sectional study design was employed in 2016 at cement packaging industry in Tuban, Indonesia. Sample size were 22 workers obtained by using simple random sampling technique. Noise level was measured at production unit with a calibrated Sound Level Meter. Workers characteristics were gathered with an appropriate questionnaire. Blood pressure and pulse were measured cross shift (before and after noise exposure) using digital tensimeter. For analyzing data, paired t-test and pearson correlation test were used. $P<0.050$ was considered statistically significant. 
Result: Noise level at all production areas were exceed the TLV, over $85 \mathrm{dBA}$. Most workers were 42 years old, had over 15 years of worked periode and $77.3 \%$ of respondents were using EPE with ear plug type. Either sistolic and diastolic blood pressure before noise exposure were normal, but after that, they were prehypertension. Mean pulse of workers before and after noise exposure were 76,64 $\mathrm{x} / \mathrm{second}$ and 86,91 $\mathrm{x} / \mathrm{second}$.

Conclusion: There were significant differences between the systolic blood pressure, diastolic and pulse before and after work. Meanwhile, there were significant associations between noise with raised systolic blood pressure, diastolic blood pressure and pulse on workers of cement packaging industry. So, preventive of noise should be controled by using convenient EPE for workers.

Keywords: Noise; systolic blood pressure; diastolic blood pressure; pulse

\section{PENDAHULUAN}

Indonesia merupakan salah satu negara industri yang sedang berkembang pesat. Teknologi modern yang digunakan untuk membantu proses produksi selain dapat meningkatkan kapasitas produksi juga dapat menghasilkan dampak negatif. Dampak negatif yang dapat timbul antara lain berupa suara atau bunyi yang dapat menimbulkan kebisingan di lingkungan kerja. Kebisingan (noise pollution) merupakan salah satu faktor yang dapat mengakibatkan timbulnya gangguan kesehatan bagi tenaga kerja, masyarakat sekitar tempat kerja maupun industri. Kebisingan juga sering menjadi penyebab timbulnya konflik dan kemarahan masyarakat yang tinggal di lingkungan dekat sumber kebisingan tersebut. Oleh karenanya sudah sewajarnya bila dilakukan upaya untuk mengendalikan kebisingan. ${ }^{1}$

Untuk melindungi tenaga kerja dari bahaya kebisingan di lingkungan industri, pemerintah telah mengeluarkan Peraturan Menteri Tenaga Kerja dan Transmigrasi No. PER/13/MEN/X/2011 tentanng Nilai Ambang Batas Faktor Fisika dan Faktor Kimia di Tempat Kerja. Dalam peraturan tersebut ditetapkan Nilai Ambang Batas (NAB) kebisingan sebesar 85 dBA. Nilai tersebut sebagai intensitas tertinggi dan merupakan nilai yang masih dapat diterima oleh pekerja tanpa mengakibatkan penyakit atau gangguan kesehatan dalam pekerjaan sehari-hari untuk waktu tidak melebihi 8 jam sehari atau 40 jam seminggu. ${ }^{2}$

Pajanan kebisingan yang terjadi dalam waktu lama dan terus menerus dapat menyebabkan berbagai gangguan kesehatan. Gangguan tersebut bisa berupa meningkatkan tekanan darah, gangguan psikologis, gangguan komunikasi, gangguan keseimbangan dan gangguan pendengaran. ${ }^{3}$ Hubungan antara kebisingan dengan timbulnya gangguan kesehatan sangat dipengaruhi oleh beberapa faktor yaitu intensitas kebisingan, frekuensi kebisingan, dan lamanya seseorang terpajan oleh suara atau bunyi bising tersebut.

Penelitian yang dilakukan oleh Hartanto menyebutkan bahwa pada karyawan unit compressor PT Inco Acidatama Tbk dengan intensitas kebisingan $89,3 \mathrm{~dB}$ dengan besar sampel yang diambil sebanyak 20 responden. Penelitian tersebut menemukan sebanyak 12 orang mengalami kenaikan tekanan darah akibat terpapar kebisingan dengan intensitas 89,3 dB. ${ }^{4}$ Penelitian Rahmawati menyatakan bahwa hasil penelitian pengaruh kebisingan terhadap denyut nadi pada tenaga kerja Bandara Ahmad Yani Semarang dengan hasil pengukuran intensitas kebisingan untuk area kerja di luar ruangan yaitu pada intensitas kebisingan 87,52 $\mathrm{dB}$ sedangkan area kerja di dalam ruangan yaitu $65,74 \mathrm{~dB} .^{5}$ Hasil pemeriksaan denyut nadi tenaga kerja menunjukan bahwa tenaga yang terpajan kebisingan $>85 \mathrm{~dB}$ dan $\leq 85 \mathrm{~dB}$ memiliki denyut nadi tidak normal yaitu sebesar $(19,4 \%)$. Hasil analisis dengan uji chi-square didapatkan nilai signifikansi $0,009(\mathrm{p}<0,05)$ yang menunjukkan bahwa kebisingan berpengaruh signifikan terhadap denyut nadi.

Hal ini didukung dengan suatu studi epidemiologi di Amerika Serikat dalam Huldani menyatakan bahwa masyarakat yang terpapar kebisingan, cenderung memiliki emosi tidak stabil. Ketidakstabilan emosi tersebut akan mengakibatkan stres. Stres yang cukup lama, akan menyebabkan terjadinya penyempitan pembuluh darah, sehingga memacu jantung untuk memompa darah lebih berat sehingga tekanan darah akan naik. Faktor yang dapat mempengaruhi tekanan darah dapat dibagi menjadi faktor yang bisa dikendalikan (misalnya olah raga, nutrisi, alkohol, stres dan merokok) dan faktor yang tidak bisa dikendalikan (contohnya ras, usia di atas 35 tahun, riwayat keluarga dengan tekanan darah tinggi, obesitas, dan penyakit ginjal). ${ }^{6}$

Industri semen merupakan salah satu industri strategis Indonesia, karena semen merupakan faktor penting dalam pembangunan dan perekonomian. Penelitian ini dilakukan di salah satu anak produsen semen terbesar di Indonesia, yang bergerak di bidang penyediaan kantong dan kemasan semen. Selain untuk memenuhi kebutuhanakan kantong dan kemasan semen bagi induk perusahaannya, perusahaan ini juga menerima pesanan dari industri semen lainnya. Industri ini didirikan pada bulan Juni tahun 1992 dan mulai beroperasi secara komersial pada tahun 1994 dengan kapasitas produksi 66 juta kantong jenis kraft sewing per tahun. Produksi setiap tahunnya semakin meningkat seiring dengan penambahan mesin pada tahun 1997, 2000, 2002, 2004, dan 2013.

Peralatan yang digunakan pada industri kemasan semen ini menimbulkan polusi suara. Berdasarkan hasil pengukuran kebisingan yang dilakukan oleh perusahaan ini di tahun 2015, pada beberapa tempat di area produksi memiliki tingkat kebisingan di atas 85 
dBA. Adapun sumber kebisingan yang ada di pabrik ini berasal dari mesin produksi yang digunakan, misalnya motor listrik, pompa, compressor, tuber, botommer dan lain-lain. Jenis kebisingan adalah kebisingan continue karena terjadi secara terusmenerus dengan frekuensi yang tetap selama masa produksi.

Berdasarkan uraian masalah tersebut maka rumusan masalah dari penelitian ini adalah "Bagaimana hubungan pajanan kebisingan dengan tekanan darah dan denyut nadi pada pekerja industri kemasan semen ?" Sedangkan tujuan dari penelitian ini adalah untuk menganalisis hubungan pajanan kebisingan dengan tekanan darah dan denyut nadi pada pekerja industri kemasan semen.

\section{METODE DAN METODE}

Penelitian ini merupakan penelitian kuantitatif dengan jenis penelitian observasional analitik, menggunakan pendekatan cross sectional. Pengambilan data penelitian dilakukan pada bulan Agustus-September 2016. Populasi penelitian ini adalah pekerja bagian produksi industri kemasan semen. Adapun besar sampel dihitung dengan rumus Slovin yaitu sebagai berikut:

$$
\begin{aligned}
n & =\frac{N}{N(d)^{2}+1} \\
& =\frac{23}{23(0,05)^{2}+1} \\
& =\frac{23}{23 \times 0,0025+1} \\
& =\frac{23}{1,06}=21,6=22
\end{aligned}
$$

Keterangan :

$$
\begin{array}{ll}
n & =\text { besar sampel yang dibutuhkan } \\
N & =\text { populasi secara keseluruhan } \\
d & =\text { tingkat kepercayaan atau ketepatan yang } \\
& \text { diinginkan }(5 \%=0,05) .
\end{array}
$$

Berdasarkan rumus tersebut, diperoleh besar sampel sebanyak 22 responden. Pengambilan sampel dilakukan dengan teknik simple random sampling. Pekerja yang menjadi responden penelitian telah menyetujui untuk berpartisipasi dalam penelitian ini, dengan menandatangani informed consent yang diberikan, setelah pekerja mendapatkan penjelasan mengenai penelitian.

Pengukuran intensitas kebisingan di area produksi menggunakan alat Sound Level Meter, dilakukan pada 5 titik yang mewakili banyaknya mesin produksi yang digunakan. Data mengenai karakteristik pekerja diperoleh melalui pengisian kuesioner oleh para pekerja. Sedangkan pengukuran tekanan darah dan denyut nadi menggunakan tensimeter digital yang dilakukan pada saat sebelum dan sesudah bekerja (cross shift). Data yang diperoleh dianalisis dengan uji paired t-test untuk mengetahui perbedaan tekanan darah dan denyut nadi pada saat sebelum dan sesudah bekerja. Analisis lain dilakukan dengan menggunakan uji korelasi pearson untuk mengetahui hubungan antara kebisingan dengan tekanan darah dan denyut nadi pekerja.

\section{HASIL DAN PEMBAHASAN}

\section{Intensitas Kebisingan}

Selama penelitian ini dilakukan, industri ini tidak ada penambahan mesin dan alat lainnya yang dapat menambah intensitas kebisingan, serta alat yang digunakan untuk operasional produksi sama, sehingga intensitas kebisingan tidak jauh berbeda dibandingkan hari-hari lainnya. Adapun jenis kebisingan yang ada di bagian produksi merupakan jenis kebisingan kontinyu yang disebabkan oleh mesin produksi yaitu mesin Tuber dan Bottomer yang beroperasi 24 jam. Namun, mesin dimatikan setiap 8 jam saat pergantian shift.

Pengukuran kebisingan dilakukan pada lima titik pengukuran yaitu di area produksi tepatnya pada Line 1, Line 2, Line 3, Line 4 dan Line 5. Kemudian data yang diperoleh dari hasil pengukuran kebisingan di lapangan disajikan dalam bentuk tabel dan selanjutnya dibandingkan dengan peraturan yang terkait. Secara rinci hasil pengukuran dadat dilihat pada tabel 1 .

Berdasarkan Peraturan Menteri Tenaga Kerja dan Transmigrasi No. PER/13/MEN/X/2011 tentang Nilai Ambang Batas Faktor Fisika dan Faktor Kimia di Tempat Kerja, dapat diketahui bahwa di semua titik pengukuran di area produksi yaitu pada Line 1,2,3,4 dan 5 tingkat kebisingannya melebihi NAB atau di atas 85 dBA. Intensitas kebisingan terendah terdapat pada Line 2 yaitu sebesar 89,1 dBA dan intensitas kebisingan tertinggi terdapat pada Line 4 yaitu sebesar 94,4 dBA. Adapun rata-ratanya sebesar 90,8 dBA. Sehingga dapat disimpulkan bahwa tingkat kebisingan di area produksi industri kemasan semen ini melebihi peraturan yang telah ditetapkan dan dapat dikategorikan sebagai zona tidak aman tanpa pelindung telinga.

Menurut Tarwaka bahwa pengendalian kebisingan salah satunya dapat di kontrol dengan pemakaian alat pelindung telinga (APT) yaitu ear plug dan ear muff. Alat pelindung telinga bisa melindungi seluruh telinga dan mengurangi dari pajanan kebisingan sampai lebih sama dengan $30 \mathrm{dBA}$. Sedangkan untuk tutup telinga (ear muff / protective caps / circumaural protectors) yaitu APT yang dapat menutupi telinga eksternal dan dapat mengurangi bising sampai dengan 40-50 dBA dan frekuensi 100$8000 \mathrm{~Hz}$. Helmet (enclosure) dapat menutupi seluruh kepala yang digunakan untuk mengurangi kebisingan 35-50 dBA pada frekuensi tinggi.? 
Tabel 1. Hasil Pengukuran Kebisingan di Industri Kemasan Semen Tahun 2016

\begin{tabular}{cccc}
\hline \multirow{2}{*}{ Titik Pengukuran } & $\begin{array}{c}\text { Intensitas } \\
\text { kebisingan }(\mathrm{dBA})\end{array}$ & $\begin{array}{c}\text { Permenakertrans No. } \\
\text { PER/13/MEN/X/2011 }\end{array}$ & \multirow{2}{*}{ Keterangan } \\
\hline Line 1 & 89,2 & $85 \mathrm{dBA}$ & Melebihi NAB \\
Line 2 & 89,1 & $85 \mathrm{dBA}$ & Melebihi NAB \\
Line 3 & 90,3 & $85 \mathrm{dBA}$ & Melebihi NAB \\
Line 4 & 94,4 & $85 \mathrm{dBA}$ & Melebihi NAB \\
Line 5 & 91,3 & $85 \mathrm{dBA}$ & Melebihi NAB \\
\hline Rata-rata & 90,8 & $85 \mathrm{dBA}$ & Melebihi NAB \\
\hline
\end{tabular}

\section{Karakteristik Responden}

Responden dalam penelitian ini adalah pekerja tetap industri kemasan semen yang bekerja di bagian produksi. Tabel distribusi frekuensi karakteristik responden berdasarkan usia, masa kerja, dan penggunaan alat pelindung telinga (APT) dapat dilihat pada Tabel 2. Diketahui bahwa usia minimal responden yaitu 37 tahun, usia maksimal 54 tahun dan sebagian besar usia responden adalah 42 tahun. Hal ini menunjukkan bahwa umur responden dalam penelitian ini seluruhnya masih kurang dari 55 tahun, sehingga dapat meminimalkan kemungkinan adanya peningkatan tekanan darah yang disebabkan oleh usia.

Pada usia lanjut (di atas 50 tahun), hipertensi ditemukan hanya berupa kenaikan darah sistolik. Tekanan sistolik terus meningkat sampai usia 80 tahun. Sedangkan tekanan diastolik akan terus meningkat pada usia 55-60 tahun. Kemudian berkurang secara perlahan atau bahkan menurun drastis. Tingginya hipertensi sejalan dengan bertambahnya umur disebabkan oleh perubahan struktur pada pembuluh darah besar, yang dapat menyebabkan peningkatan tekanan darah sistolik. ${ }^{8}$

Sebagian besar pekerja di indusrti kemasan semen berusia kurang dari 50 tahun, sehingga risiko terjadinya kenaikan tekanan darah lebih kecil. Karena pada usia kurang dari 50 tahun kondisi pembuluh darah manusia masih normal dan elastis.

Masa kerja adalah lamanya waktu yang dihitung sejak pekerja memiliki hubungan kerja atau sejak pertama kali pekerja di perusahaan tertentu berdasarkan pada perjanjian kerja. Masa kerja dapat diasumsikan sebagai lamanya pekerja menerima pajanan kebisingan. Pada penelitian ini menunjukkan bahwa sebagian besar pekerja mempunyai masa kerja lebih dari 15 tahun, sebanyak $17(77,3 \%)$ responden dari 22 responden. Seluruh karyawan mempunyai masa kerja lebih dari 10 tahun sehingga risiko terjadinya gangguan akibat kebisingan di tempat kerja lebih tinggi. Hal ini menjadi sesuatu penting untuk diketahui agar dapat dilakukan penanganan lebih lanjut apabila terjadi gangguan akibat kebisingan.

Upaya preventif terhadap masalah kesehatan yang dapat terjadi karena polusi suara yang ditimbulkan oleh mesin yang digunakan harus dilakukan. Tabel 2 menunjukkan bahwa sebagian besar pekerja telah menggunakan APT dengan kategori sering (apabila ketika bekerja responden memakai alat pelindung telinga minimal 3 hari kerja dalam satu minggu). Adapun jenis APT yang digunakan pekerja sebagian besar adalah jenis ear plug yaitu sebanyak 17 responden $(77,3 \%)$.

Tabel 2. Distribusi frekuensi karakteristik responden berdasarkan usia, masa kerja dan penggunaan APT di Industri Kemasan Semen Tahun 2016

\begin{tabular}{clcc}
\hline $\begin{array}{c}\text { Karakteristik } \\
\text { Responden }\end{array}$ & Kategori & $\begin{array}{c}\text { Jumlah } \\
(\mathrm{n})\end{array}$ & $\begin{array}{c}\text { Presentase } \\
(\mathbf{\%})\end{array}$ \\
\hline Usia & $>35-45$ & 11 & 50,0 \\
& $>45-55$ & 11 & 50,0 \\
Jumlah & & $\mathbf{2 2}$ & $\mathbf{1 0 0 , 0}$ \\
\hline Masa Kerja & $>10-15$ Tahun & 5 & 22,7 \\
& $>15$ Tahun & 17 & 77,3 \\
Jumlah & Selalu & $\mathbf{2 2}$ & $\mathbf{1 0 0 , 0}$ \\
\hline Penggunaan APT & Sering & 8 & 36,4 \\
& Jarang & 9 & 40,9 \\
Jumlah & Tidak Pernah & 4 & 18,2 \\
Jenis APT & Ear Plug & 1 & 4,5 \\
Jumlah & Ear Muff & $\mathbf{2 2}$ & $\mathbf{1 0 0 , 0}$ \\
\hline
\end{tabular}


Upaya yang telah dilakukan perusahaan untuk mengurangi pajanan kebisingan yaitu dengan menyediakan APT untuk karyawan bagian produksi berupa APT jenis ear plug. Namun berdasarkan hasil pengamatan, terdapat beberapa pekerja yang tidak menggunakan APT ataupun jika menggunakan APT tidak digunakan secara benar, yaitu hanya memakai ear plug pada salah satu telinga saja. Menurut pengakuan pekerja, hal tersebut dilakukan karena merasa tidak nyaman saat menggunakan APT tersebut dalam jangka waktu yang lama. Ketidaknyamanan tersebut mungkin disebabkan oleh ear plug yang digunakan terbuat dari bahan karet yang digunakan berulang kali. Adapun sanksi jika pekerja tidak menggunakan ear plug saat bekerja hanya berupa teguran lisan oleh supervisor dan meski hal tersebut dilakukan berulang kali tidak ada sanksi yang lebih berat, misalnya berupa denda ataupun hukuman lainnya.

Idealnya dalam pemilihan jenis ear plug seharusnya dipilih sesuai dengan bentuk dan saluran telinga pemakainya. Hal ini disebabkan karena ukuran dan bentuk saluran telinga setiap individu berbeda antara individu satu dengan lainnya. Sehingga ear plug yang terbuat dari bahan kapas dan spon akan lebih nyaman untuk digunakan karena ear plug dari bahan kapas dan spon bisa menyesuaikan dengan ukuran dan bentuk telinga pemakainya. Hal ini dapat mengurangi rasa sakit dan dapat terasa lebih nyaman digunakan. Ear plug sebaiknya juga diganti secara periodik, sehingga dapat berfungsi maksimal untuk melindungi telinga dan terjaga kebersihannya. ${ }^{9}$

Meskipun pihak perusahaan sudah menyediakan APT jenis ear plug, namun akan lebih baik jika perusahaan menyediakan APT jenis ear muff. Penggunaan APT jenis ear muff dapat mengurangi kebisingan sebesar 40-50 dB. Sedangkan APT jenis ear plug hanya bisa mengurangi kebisingan hingga $30 \mathrm{~dB}$. Selain penggunaan APT, di area produksi ini tidak ditemukan pengendalian lain seperti memasang peredam suara mesin. Adapun rotasi pekerja hanya dilakukan tetap pada area produksi tersebut, yaitu dengan berpindah dari line yang satu ke line lainnya.

\section{Tekanan Darah}

Pengukuran tekanan darah pekerja dilakukan dua kali dengan cara cross shift, yaitu sebelum bekerja dan setelah bekerja. Pengukuran tekanan darah dilakukan dengan menggunakan tensimeter digital. Peningkatan tekanan darah merupakan selisih tekanan darah setelah kerja dan tekanan darah sebelum kerja. Data hasil pengukuran tekanan darah sebelum dan setelah bekerja dapat dilihat pada Tabel 3.

Hasil pengukuran tekanan darah sistole yang dilakukan sebelum kerja didapatkan nilai minimum sebesar $96 \mathrm{mmHg}$, nilai maksimum $129 \mathrm{mmHg}$ dan nilai rata-ratanya $116,50 \mathrm{mmHg}$. Menurut Joint National Commission (JNC) VII (2003) nilai rata-rata tekanan darah sistole sebelum kerja tersebut termasuk dalam kategori normal. Sedangkan pengukuran tekanan darah sistole yang dilakukan setelah bekerja menunjukkan nilai minimum $110 \mathrm{mmHg}$, nilai maksimum $152 \mathrm{mmHg}$ dan nilai rata-ratanya 128,09 mmHg. Menurut Joint National Commission (JNC) VII (2003) nilai rata-rata tekanan darah sistole setelah kerja tersebut termasuk dalam kategori prehipertensi.

Tabel 3. Pengukuran Tekanan Darah Sistole Sebelum dan Setelah Bekerja pada Karyawan di PT Industri Kemasan Semen Gresik (IKSG) Tahun 2016.

\begin{tabular}{lccc}
\hline Tekanan Darah & $\begin{array}{c}\text { Minimum } \\
(\mathrm{mmHg})\end{array}$ & $\begin{array}{c}\text { Maksimum } \\
(\mathrm{mmHg})\end{array}$ & $\begin{array}{c}\text { Rata-rata } \\
(\mathrm{mmHg})\end{array}$ \\
\hline Sistole sebelum kerja & 96 & 129 & 116,50 \\
Sistole setelah kerja & 110 & 152 & 128,09
\end{tabular}

Hasil uji statistik $t$-test didapatkan $\mathrm{p}=0,000<\alpha 0,05$

\begin{tabular}{llll}
\hline Diastole sebelum kerja & 69 & 88 & 76,41 \\
Diastole setelah kerja & 74 & 93 & 82,27
\end{tabular}

Hasil uji statistik $t$-test didapatkan $\mathrm{p}=0,000<\alpha 0,05$

Peningkatan tekanan darah sistole pada pekerja di bagian produksi industri kemasan semen memiliki nilai rata-rata peningkatan sebesar $11,59 \mathrm{mmHg}$. Terjadi peningkatan tekanan darah sistole pekerja saat sebelum dan sesudah bekerja. Hal ini sejalan dengan penelitian yang dilakukan Babba didapatkan nilai rata-rata peningkatan tekanan darah sistole sebesar 19,2 mmHg. ${ }^{10}$ Penelitian lain juga menunjukkan tren nilai rata-rata peningkatan tekanan darah sistole sebesar 3,58 mmHg. ${ }^{11}$
Untuk pengukuran tekanan darah diastole yang dilakukan sebelum kerja didapatkan nilai minimum sebesar $69 \mathrm{mmHg}$, nilai maksimum $88 \mathrm{mmHg}$ dan nilai rata-ratanya $76,41 \mathrm{mmHg}$. Menurut Joint National Commission (JNC) VII (2003) nilai rata-rata tekanan darah diastole sebelum kerja tersebut termasuk dalam kategori normal. Sedangkan hasil pengukuran tekanan darah diastole setelah kerja didapatkan nilai minimum sebesar $74 \mathrm{mmHg}$, nilai maksimum $93 \mathrm{mmHg}$ dan nilai rata-ratanya $82,27 \mathrm{mmHg}$. Menurut Joint National Commission (JNC) VII (2003) nilai rata-rata tekanan 
darah diastole sesudah kerja tersebut termasuk dalam kategori pre hipertensi.

Adapun peningkatan tekanan darah diastole pada pekerja bagian produksi di industri kemasan semen memiliki nilai rata-rata peningkatan sebesar 5,86 mmHg. Terjadi peningkatan tekanan darah diastole pekerja saat sebelum dan sesudah bekerja. Hal ini sesuai dengan penelitian Babba yang menunjukkan bahwa terdapat peningkatan darah diastole dengan ratarata sebesar $6,8 \mathrm{mmHg} .{ }^{10}$ Sedangkan pada penelitian Huldani didapatkan hasil rata-rata peningkatan darah diastole sebesar 1,09 mmHg. ${ }^{11}$

Berdasarkan hasil analisis dengan uji paired t-test terhadap tekanan darah sistole sebelum dan sesudah bekerja didapatkan nilai signifikansi $\rho=0,000<\alpha 0,05$ yang artinya ada perbedaan yang signifikan antara tekanan darah sistole sebelum dan sesudah bekerja pada pekerja yang terpajan bising di industri kemasan semen.

Berdasarkan hasil analisis dengan uji paired t-test terhadap tekanan darah diastole sebelum dan sesudah bekerja didapatkan nilai signifikansi $=0,000<\alpha(0,05)$ yang berarti ada perbedaan yang signifikan antara tekanan darah diastole sebelum dan sesudah bekerja pada pekerja yang terpajan bising di industri kemasan semen.

Hal ini sejalan dengan penelitian Syidiq yang menyatakan bahwa ada pengaruh yang bermakna antara tingkat kebisingan terhadap kenaikan tekanan darah pekerja di PT. Pertani (Persero) Cabang Surakarta, dengan nilai siknifikansi tekanan darah sistolik dan diastolik (p) 0,033 atau $\mathrm{p} \leq 0,05$ dengan $\mathrm{t}$ hitung 2,297. ${ }^{12}$ Pada penelitian Dewi juga menyebutkan ada perbedaan tekanan darah pada karyawan terpapar kebisingan di atas dan di bawah nilai ambang batas (NAB) pada bagian produksi di PT. Iskandar Indah Textile Surakarta. ${ }^{13}$

Intensitas kebisingan yang mencapai minimal 60 $\mathrm{dB}$ dapat meningkatkan hormon stres seperti epineprin, non-epineprin dan kortisol yang ada di dalam tubuh manusia. Sehingga mengakibatkan terjadinya perubahan detak jantung dan tekanan darah. Kebisingan yang terjadi terus-menerus atau continue yang diterima seseorang akan berdampak pada terjadinya gangguan fisiologis jaringan otot dalam tubuh sehingga memicu emosi yang tidak stabil. Ketidakstabilan emosi tersebut akan berpengaruh pada kerja jantung untuk memompa darah lebih keras ke seluruh tubuh. Apabila hal ini terjadi dalam waktu yang lama maka dapat mengakibatkan tekanan darah naik sehingga timbul hipertensi. ${ }^{14}$

\section{Denyut Nadi}

Pengukuran denyut nadi dilakukan sebanyak dua kali yaitu pada saat sebelum kerja dan sesudah kerja (cross shift). Peningkatan denyut nadi merupakan selisih tekanan darah setelah kerja dan tekanan darah sebelum kerja. Pengukuran denyut nadi dilakukan dengan alat tensimeter digital yang telah dikalibrasi. Tabel 4 adalah hasil pengukuran denyut nadi pada pekerja bagian produksi industri kemasan semen. Dapat diketahui bahwa rata-rata peningkatan denyut nadi pada responden sebesar 10,27 x/menit. Hal ini sejalan dengan penelitian Perdana (2010) yang menyatakan bahwa ada hubungan antara intensitas kebisingan dengan perubahan denyut nadi $(\mathrm{p}=0,00$ $<\alpha=0,05)$.

Tabel 4. Pengukuran Denyut Nadi Sebelum dan Setelah Bekerja di Industri Kemasan Semen Tahun 2016.

\begin{tabular}{lccc}
\hline Tekanan Darah & $\begin{array}{c}\text { Min } \\
(\mathrm{x} / \mathrm{menit})\end{array}$ & $\begin{array}{c}\text { Max } \\
(\mathrm{x} / \text { menit })\end{array}$ & $\begin{array}{c}\text { Rata-rata } \\
(\mathrm{x} / \text { menit })\end{array}$ \\
\hline $\begin{array}{l}\text { Denyut nadi } \\
\text { sebelum kerja }\end{array}$ & 72 & 87 & 76,64 \\
$\begin{array}{l}\text { Denyut nadi } \\
\text { setelah kerja }\end{array}$ & 77 & 94 & 86,91 \\
\hline
\end{tabular}

Berdasarkan hasil analisis dengan uji paired t-test didapatkan nilai signifikansi $0,000(<\alpha 0,05)$ yang artinya ada perbedaan yang signifikan antara denyut nadi sebelum dan sesudah bekerja pada pekerja yang terpajan bising di industri kemasan semen. Hal ini sejalan dengan penelitian Dewi yang menunjukkan bahwa ada perbedaan nadi kerja pada karyawan terpapar intensitas kebisingan di atas dan di bawah nilai ambang batas (NAB) pada bagian produksi di PT. Iskandar Indah Textile Surakarta. ${ }^{13}$ Hal ini terjadi karena pajanan kebisingan yang terus-menerus dapat memicu terjadinya peningkatan hormon stres sehingga terjadi penyempitan pembuluh darah dan mengakibatkan peningkatan denyut nadi pada responden. Denyut nadi yang cepat merupakan indikasi bahwa seseorang mengalami beban kerja fisik, mental, stres dan kelelahan kerja. Jika hal ini tidak segera dikendalikan dan terjadi secara terus menerus maka akan mengakibatkan kecelakaan kerja, sehingga dapat menurunkan produktivitas kerja yang akan mengakibatkan kerugian materiil.

\section{Hubungan Pajanan Kebisingan dengan Kenaikan Tekanan Darah Sistole dan Diastole}

Berdasarkan hasil analisis dengan uji korelasi pearson didapatkan nilai signifikansi $\rho=0,037<$ $\alpha=0,05$ yang artinya ada hubungan antara kebisingan dengan kenaikan tekanan darah sistole pada karyawan bagian produksi industri kemasan semen. Dengan koefisien korelasi sebesar 0,448, yang artinya bahwa korelasi yang terjadi adalah korelasi positif dan hubungan yang terjadi antara kebisingan dan tekanan darah sistole berkorelasi lemah.

Sedangkan pada hasil uji korelasi pearson antara kebisingan dengan tekanan darah diastole diperoleh nilai $\rho=0,045<\alpha=0,05$ yang artinya artinya ada hubungan antara kebisingan dengan kenaikan tekanan darah diastole pada pekerja industri kemasan semen. Koefisien korelasi pearson yang dihasilkan adalah 0,431 yang menunjukkan bahwa korelasi yang terjadi adalah korelasi positif dan hubungan yang terjadi 
antara kebisingan dan tekanan darah diastole berkorelasi lemah.

Hasil penelitian ini sejalan dengan Montolalu dkk, yang menyatakan bahwa ada hubungan yang signifikan antara intensitas bising terhadap tekanan darah sistolik maupun diastolik sesuai hasil analisis bivariat dari data yang diperoleh melalui uji exact fisher menunjukan nilai $\mathrm{p}=0,032(\mathrm{p}<0,05)$ untuk hubungan intensitas kebisingan terhadap tekanan darah sistolik dan $\mathrm{p}$ $=0,018(\mathrm{p}<0,05)$ untuk hubungan intensitas bising terhadap tekanan darah diastolik. ${ }^{15}$ Menurut Babba dalam penelitiannya di PT Semen Tonasa Maros, menunjukkan bahwa ada hubungan yang signifikan antara intensitas kebisingan di lingkungan kerja dengan peningkatan tekanan darah sistolik dan tekanan darah diastolik pekerja. ${ }^{10}$

Menurut Hermawati yang menyebutkan bahwa kebisingan dapat mengganggu perhatian, sehingga konsentrasi dan kesigapan mental menurun. Efek pada syaraf otonom terlihat sebagai kenaikan tekanan darah, percepatan denyut jantung, pengerutan pembuluh darah kulit, bertambah cepatnya metabolisme, menurunnya aktivitas alat pencernaan. Hal ini didukung studi epidemiologi di Amerika Serikat. Peneliti tersebut mengaitkan masyarakat, kebisingan, serta risiko terjangkit penyakit hipertensi. Hasil penelitian tersebut menyebutkan bahwa masyarakat yang terpapar kebisingan, cenderung memiliki emosi yang tidak stabil. Ketidakstabilan emosi tersebut akan mengakibatkan stres. Stres yang cukup lama, akan menyebabkan terjadinya penyempitan pembuluh darah, sehingga memacu jantung untuk bekerja lebih keras agar dapat memompa darah ke seluruh tubuh. Dalam waktu yang lama, tekanan darah akan naik, dan inilah yang disebut hipertensi.

Kebisingan yang ditimbulkan oleh mesin tuber dan bottomer di area produksi industri kemasan semen memiliki hubungan yang signifikan terhadap tekanan darah pekerja yang berupa kenaikan tekanan darah, baik sistole maupun diastole. Kenaikan tekanan darah tersebut terjadi setelah pekerja terpapar kebisingan sehingga menyebabkan pekerja menjadi stres. Keadaan stres ini akan meningkatkan sekresi hormon adrenalin pada peredaran darah yang selanjutnya terjadi kenaikan tekanan darah. ${ }^{9}$

\section{Hubungan Pajanan Kebisingan dengan Denyut Nadi}

Berdasarkan analisis data dengan menggunakan uji korelasi pearson antara kebisingan dan denyut nadi diperoleh nilai $\mathrm{p}=0,017<\alpha=0,05$ yang artinya artinya ada hubungan antara kebisingan dengan kenaikan denyut pada pekerja bagian produksi industri kemasan semen. Koefisien korelasi sebesar 0,502 yang menunjukkan bahwa korelasi yang terjadi adalah korelasi positif dan hubungan yang terjadi antara kebisingan dan denyut nadi menunjukan hubungan korelasi yang lemah.

Hasil penelitian ini sejalan dengan penelitian yang dilakukan Dewi tentang perbedaan nadi kerja dan tekanan darah pada karyawan terpapar kebisingan di atas dan di bawah nilai ambang batas (NAB) pada bagian produksi di PT. Iskandar Indah Printing Textile Surakarta. Penelitian ini menyebutkan bahwa ada perbedaan nadi kerja pada karyawan terpapar kebisingan di atas dan di bawah nilai ambang batas dengan menggunakan uji Mann Whitney-U mendapat nilai nilai $\mathrm{p}(0,000)<\alpha=0,05$. $^{13}$

\section{SIMPULAN}

Tingkat kebisingan lingkungan kerja pada area produksi industri kemasan semen berkisar antara 89,1 sampai 94,4 dB sehingga tingkat kebisingan tersebut masih di atas NAB yang ditetapkan dalam Peraturan Menteri Tenaga Kerja dan Transmigrasi No. PER/13/MEN/X/2011 tentang Nilai Ambang Batas Faktor Fisika dan Faktor Kimia di Tempat Kerja.

Sebagian besar usia responden adalah 42 tahun dengan masa kerja $>15$ tahun dan sebagian besar responden sering menggunakan APT (Alat Pelindung Telinga) jenis ear plug. Untuk hasil pengukuran tekanan darah menunjukkan bahwa ada perbedaan tekanan darah sistole dan diastole sebelum dan sesudah bekerja pada pekerja yang terpajan bising di industri kemasan semen. Adapun nilai rata-rata peningkatan tekanan darah sistole sebesar $11,59 \mathrm{mmHg}$ dan peningkatan tekanan darah diastole sebesar 5,86 $\mathrm{mmHg}$.

Hasil pengukuran denyut nadi menunjukkan bahwa ada perbedaan yang signifikan antara denyut nadi sebelum dan sesudah bekerja pada pekerja yang terpajan bising di industri kemasan semen. Adapun rata-rata peningkatan denyut nadi sebesar 10,27 $\mathrm{x} /$ menit.

\section{DAFTAR PUSTAKA}

1. Chandra A. Tehnik Kesehatan dan Keselamatan Kerja Industri. Yogyakarta: Graha Ilmu, 2009.

2. Menteri Tenaga Kerja dan Transmigrasi RI. Peraturan Menteri Tenaga Kerja dan Transmigrasi No. PER/13/MEN/X/2011 tentang Nilai Ambang Batas Faktor Fisika dan Faktor Kimia di Tempat Kerja. Jakarta, 2001.

3. Buchari. Kebisingan Industri dan Hearing Conservation Program. Medan: Universitas Sumatra Utara, 2007.

4. Hartanto, D. Hubungan Kebisingan dengan Tekanan Darah Pada Karyawan Unit compressor PT. Indo Acidatama Tbk. Kemiri, Kebakkramat, Karanganyar. Karya Tulis Ilmiah. Universitas Sebelas Maret, 2011.

5. Rahmawarti A. Pengaruh Kebisingan terhadap Denyut Nadi pada Tenaga Kerja di Bandara Ahmad Yani Semarang. Thesis. Fakultas Kedokteran Universitas Sultan Agung Semarang, 2014.

6. McKinley. Factor That Affect Blood Pressure. University of Illinois. Diakses dari http://www.mckinley.illinois.edu/handouts/blood pressure_factors.html Fakultas Kedokteran Program D-III Hiperkes dan Keselamatan Kerja, 2008. 
7. Tarwaka. Keselamatan dan Kesehatan Kerja. Manajemen dan implementasi K3 di tempat kerja. Surakarta: Harapan Press, 2008.

8. Departemen Kesehatan RI. Pedoman Teknis Penemuan dan Tatalaksana Penyakit Hipertensi. Jakarta, 2006.

9. Siswati. Hubungan Pajanan Kebisingan dengan Tekanan Darah, Denyut Nadi dan Gangguan Pendengaran pada Karyawan PT Industri Kemasan Semen Gresik (IKSG). Skripsi. Universitas Airlangga Surabaya, 2017.

10. Babba J. Hubungan AntaraIntensitas Kebisingan di LingkunganKerja dengan Peningkatan Tekanan Darah (Penelitian pada Karyawan PT.Semen Tonasa di Kabupaten Pangkep Sulawesi Selatan). Tesis. Semarang: Universitas Diponegoro, 2007.

11. Huldani. Kebisingan Mempengaruhi Tekanan Darah Pekerja PT. PLN (Persero) Sektor Barito PLTD Trisakti. Banjarmasin: Universitas Lambung Mangkurat Banjarbaru, 2012.
12. Syidiq M. Pengaruh Intensitas Kebisingan terhadap Kenaikan Tekanan Darah pada Pekerja di PT. Pertani (Persero) Cabang Surakarta. Skripsi. Universitas Muhammadiayah Surakarta, 2013.

13. Dewi DT. Perbedaan Nadi Kerja dan Tekanan Darah pada Karyawan Terpapar Intensitas Kebisingan Di Atas dan Di Bawah Nilai Ambang Batas (NAB) Pada Bagian Produksi di PT. Iskandar Indah Printing Textile Surakarta. Skripsi. Universitas Muhammadiyah Surakarta, 2016.

14. Tambunan ST. Kebisingan di Tempat Kerja (Occuptional Health). Yogyakarta: Andi, 2005.

15. Montolalu SS, Supit W, Danes WR. 2014. Hubungan Kebisingan Terhadap Tekanan Darah Pada Pekerja Lapangan PT. Gapura Angkasa Di Bandar Udara Sam Ratulangi, Manado. Jurnal eBiomedik 2014, Vol 2 (1): 1-7. 